\title{
Is experience in the public sector associated with Big Five personality aspects?
}

\section{¿Se asocia la experiencia en el sector público con aspectos de los Cinco Grandes de la personalidad?}

\author{
Federico R. León ${ }^{\mathrm{a}^{*}}$ \\ aUniversidad Científica del Sur, Perú
}

\begin{abstract}
The hypothesis that employees with experience in the public sector differ in personality aspects from those with less or no experience, suggested by the concept of personorganization fit, was tested among 711 participants in executive extension courses of a Peruvian university who filled-in the Big Five Aspect Scales. Whereas significant differences in various personality aspects were observed along age and between males and females, public sector experience only predicted greater Openness. Women outperformed men in Openness and a significant gender $\mathrm{x}$ time in public sector interaction revealed that prediction of Openness from the public-sector experience was more pronounced among men. The findings suggest that, in the population studied, little personality differences are attributable to experience in the public sector. Studies are needed to evaluate the external validity of the findings.
\end{abstract}

Keywords: experience in public sector, personality, aspects of the Big Five, Peru, openness.

\section{Para citar este artículo:}

Léon, F. (2017). Is experience in the public sector associated with Big Five personality aspects? Liberabit, 23(1), 103-109. doi: 10.24265/liberabit.2017.v23n1.07

\section{Resumen}

El concepto de ajuste persona-organización sugiere que empleados con experiencia en el sector público difieren en aspectos de la personalidad de aquellos con escasa o ninguna experiencia. Cuando se puso a prueba esta hipótesis entre 711 participantes en cursos de extensión para ejecutivos de una universidad peruana, se observó diferencias significativas en las Escalas de Aspectos de los Cinco Grandes entre hombres y mujeres y según la edad, pero la experiencia en el sector público solo predijo mayor Apertura. Las mujeres presentaron mayor Apertura que los hombres y una interacción significativa de género x tiempo en el sector público reveló que la predicción de Apertura desde la experiencia en el sector público era más pronunciada entre los hombres. Los hallazgos sugieren que, en la población estudiada, pocas diferencias de personalidad son atribuibles a la experiencia en el sector público. Se necesita estudios que evalúen la validez externa de los hallazgos.

Palabras clave: experiencia en el sector público, personalidad, aspectos de los Cinco Grandes, Perú, apertura.

Este es un artículo Open Access bajo la licencia Creative Commons Atribución-NoComercial-CompartirIgual 4.0

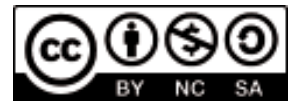




\section{Introduction}

The public and private sectors present a number of important differences. First, the public sector is not designed to make a profit and, therefore, there is no competition in government settings in the sense of organizations trying to entice customers away from their competitors. Thus, in reference to the Competing Values Framework (Hartnell, Ou, \& Kinicki, 2011), the organizational culture of public sector agencies probably conforms to control rather than competition values; that is, employees are probably more required by the organizational culture to conform to established rules and procedures and less induced to produce rapid results. Second, politicians have direct or indirect influence in the allocation of resources to public sector agencies and may interfere in the process of personnel recruitment and selection as they try to insert their protégés into the system, both at higher management and rank-andfile levels. As a consequence, such principles of management as equitable treatment may be easily transgressed (Flynn, 1993) and the public sector has come to be described as an operating environment characterized by ill-structured and wicked problems (Van der Heijden, 2006).

This study addresses the hypothesis that time spent working in the public sector predicts personality traits. Saks and Ashforth (1997) suggested that having a high person-environment fits will lead to a more positive work experience and less negative affect, and consequently individuals will be more likely to remain in that environment. There is considerable empirical evidence that person-job and person-organization fit are associated with such organizational outcomes as job satisfaction, intention to quit, work-related stress, prosocial behaviors such as organizational citizenship behaviors and teamwork, and ethical behavior and work performance (Erdogan \& Bauer, 2005; Kristof, 1996; Lyons, Brenner, \& Fassinger, 2005; Lyons \& O’Brien, 2006; Roberts \& Robins, 2004; Saks \& Ashforth, 1997; Sekiguchi, 2004). Therefore, employees who are attracted to the public sector and remain in it can be expected to be those whose personality, to some extent, fit the sector. However, the personality of public sector employees, if there is one, has not been described. Psychological studies of public sector employees have addressed, for example, relationships between Big Five personality traits and job engagement (e.g., N. Zaidi, Wajid, F. Zaidi, G. Zaidi, \& M. Zaidi, 2013), job performance (Cooper, Knotts, McCord, \& Johnson, 2013), and counterproductive work behaviors (Raman, Sambasivan, \& Kumar, 2016), but the extent to which permanence in the public sector is associated with specific personality traits has not been addressed.

The study approaches the task utilizing the 10 aspects of the Big Five framework. DeYoung, Quilty, and Peterson (2007) demonstrated the existence of two correlated but distinct aspects within each of the five broad domains. Within Neuroticism, they distinguished Volatility from Withdrawal. The former is associated with emotional lability, irritability or anger, and difficulty controlling emotional impulses whereas the latter is characterized by facets such as Depression, Anxiety, and Vulnerability, which imply problems of inhibition and negative affect directed inward. Agreeableness contains Compassion (defined by facets such as Warmth, Sympathy, Tenderness), an aspect strongly related to emotional affiliation, and Politeness (defined by facets such as Cooperation, Compliance, Straightforwardness), a more reasoned consideration of and respect for others' needs and desires. Conscientiousness entails Industriousness and Orderliness. The former refers to purpose, efficiency, and self-discipline and the latter to dutifulness, order, and perfectionism. Assertiveness and Enthusiasm are the two aspects of Extraversion. Assertiveness implies agency and dominance whereas Enthusiasm describes a gregarious and friendly person with positive emotionality. Finally, Intellect (an exploration of ideas, evidence, mainly through reasoning) and Openness (experiencing art, feelings, nature) are differentiated as two forms of the disposition to explore. DeYoung et al. (2007) showed that a subdivision of the Big Five 
personality domains into 10 aspects not only is empirically justified but has a biological substrate. Subsequent studies have demonstrated the usefulness of this categorization for identifying gender differences in personality (Weisberg, DeYoung, \& Hirsh, 2011) and explaining political (Hirsh, DeYoung, $\mathrm{Xu}$, \& Peterson, 2010), interpersonal (DeYoung, Weisberg, Quilty, \& Peterson, 2013), and economic and health behavior (Rustichini, DeYoung, Anderson, \& Burks, 2012), as well as cognitive ability (DeYoung, Quilty, Peterson, \& Gray, 2014) and artistic and scientific productivity (Kaufman et al., 2015).

\section{Method}

\section{Context and participants}

ESAN, a university based in Lima, Peru launched in 2013 an Online Management Extension Program for Executives as an alternative to its traditional faceto-face Executive Extension Program. Students of both programs were targeted for the present study and invited to participate via electronic mail. The offer of their personality profile when the data were collected was used as incentive. The sample was strongly biased toward the private sector. Four hundred ninety-two (492) cases with 0 years working in the public sector had on average 10.55 years working in the private sector. Two hundred eleven (211) cases with 1 or more years in the public sector had on average 4.75 years working in the public sector and 7.93 years in the private sector.

\section{Measurements}

The 100-item Big Five Aspect Scales of DeYoung et al. (2007) were forward-back translated into Spanish and utilized to measure the 10 aspects among participants. Their internal consistency reliability was satisfactory for research purposes (Volatility $\alpha=$ .79; Withdrawal $\alpha=.73$; Compassion $\alpha=.75$; Politeness $\alpha=.81$; Industriousness $\alpha=.58$; Orderliness $\alpha=.58$; Enthusiasm $\alpha=.77$; Assertiveness $\alpha=.77$; Intellect $\alpha=.78$; Openness $\alpha=$.66). Data on gender (female $=1$, male $=2$ ), age, and numbers of years working in the public and private sectors were also collected.

\section{Analytic Strategy}

To simplify the analyses, age outliers were excluded and the sample was limited to participants aged 22-55 $(N=711)$. Bootstrapping was used in hypothesis testing to avoid problems with variables which might not satisfy the statistical assumptions.

\section{Results}

The 10-aspect structure of the Big Five Aspect Scales was validated through a confirmatory factor analysis that yielded satisfactory adjustment indices $(\chi 2 / \mathrm{df}=2.060 ; \mathrm{CFI}=.951 ; \mathrm{TLI}=.949 ; \mathrm{RMSEA}=$ .039 ; SRMR $=.057)$. The loadings were .44 (Volatility), .99 (Withdrawal), .38 (Compassion), .46 (Politeness), .99 (Industriousness), .42 (Orderliness), $\quad .58 \quad$ (Enthusiasm), $\quad .99$ (Assertiveness), .76 (Intellect), and .40 (Openness). However, the expected Big Five structure failed to materialize when León, Morales, Vértiz, and BurgaLeón (2017) tried an exploratory factor analysis. Model I in Table 1 shows that Volatility (Vol), Withdrawal (Wit), and Enthusiasm (Ent) decreased with age; Industriousness (Ind), Orderliness (Ord), and Intellect (Int) increased with age; and Compassion (Com), Politeness (Pol), Assertiveness (Ass), and Openness (Ope) did not change significantly in this sample. Controlling for age, females presented greater Withdrawal, Compassion, and Politeness scores and smaller Intellect scores than males (Model II in Table 1). Controlling for age and gender, time in the public sector did not make a difference in any of the ten aspects (Model III in Table 1). However, when the gender $\mathrm{x}$ time in public sector interaction was included in the regression, this variable, as well as gender and time in the public sector, achieved statistical significance (Model IV in Table 1). Figure 1 depicts the interaction using the 0 years versus 1 or more years in the public sector dichotomy to compare private and public sector employees. 


\section{Table 1}

Standardized coefficients for the independent regression of each of 10 personality aspects on age (Model I); age and gender (Model II); age, gender, and time in public sector (Model III); and age, gender, time in public sector, and gender $x$ time in public sector (Model IV)

\begin{tabular}{|c|c|c|c|c|c|c|c|c|c|c|}
\hline Models and Predictors & Vol & Wit & Com & Pol & Ind & Ord & Ent & Ass & Int & Ope \\
\hline \multicolumn{11}{|l|}{ Model I } \\
\hline Age & $-.13^{* *}$ & $.17 * *$ & -.06 & .05 & $.16^{* *}$ & $.20 * *$ & $-.09 *$ & .04 & $.08 *$ & -.05 \\
\hline \multicolumn{11}{|l|}{ Model II } \\
\hline Age & $-.11^{* *}$ & $-.15 * *$ & -.03 & $.09 *$ & $.17 * *$ & $.20 * *$ & $-.08 *$ & .04 & .05 & -.03 \\
\hline Gender $($ Female $=0$, Male $=1)$ & -.07 & $-.08 *$ & $-.16^{* *}$ & $-.18 * *$ & -.03 & .04 & -.07 & .02 & $.13^{* *}$ & -.07 \\
\hline \multicolumn{11}{|l|}{ Model III } \\
\hline Age & $-.12 * *$ & $-.16 * *$ & -.03 & $.08^{*}$ & $.17^{* *}$ & $.19 * *$ & -.07 & .05 & .07 & -.02 \\
\hline Gender $($ Female $=0$, Male $=1$ ) & -.06 & $-.08 *$ & $-.16^{* *}$ & $-.17 * *$ & -.02 & .04 & -.07 & .02 & $.13^{* *}$ & -.08 \\
\hline Time in public sector & .03 & .01 & .00 & -.00 & .01 & -.00 & -.04 & -.03 & -.03 & -.05 \\
\hline \multicolumn{11}{|l|}{ Model IV } \\
\hline Age & $-.12 * *$ & $-.16^{* *}$ & -.03 & $.08^{*}$ & $.17 * *$ & $.19^{* *}$ & -.07 & .05 & .07 & -.02 \\
\hline Gender $($ Female $=0$, Male $=1)$ & -.10 & -.08 & $-.24 * *$ & -.15 & -.11 & .02 & -.16 & -.11 & .05 & $-.24 *$ \\
\hline Time in public sector & .02 & .01 & -.02 & .01 & -.01 & -.01 & -.06 & -.06 & -.05 & $-.09 *$ \\
\hline Gender $\mathrm{x}$ time in public sector & .04 & -.00 & .10 & -.03 & .10 & .03 & .11 & .14 & .09 & $.18 *$ \\
\hline
\end{tabular}

Note Vol = volatility, Wit $=$ withdrawal, Com $=$ compassion, Pol $=$ politeness, Ind $=$ industry, Ord $=$ Orderliness, Ent $=$ enthusiasm, Ass $=$ assertiveness, Int $=$ intellect, Ope $=$ openness.

$* p<.05, * * p<.01$, after bootstrapping.

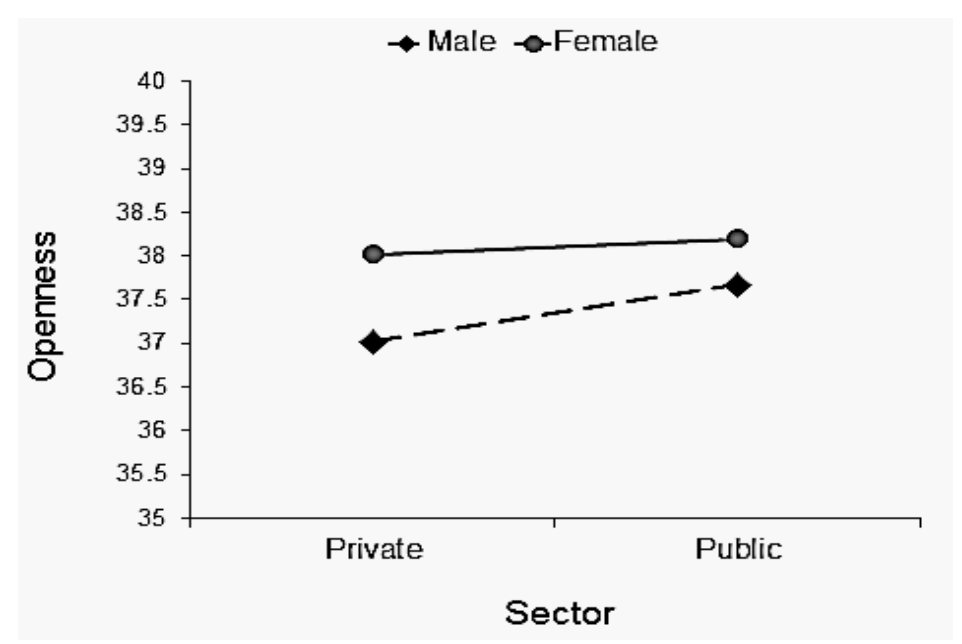

Figure 1. Adjusted means for openness among males and females classified into private or public sector. 


\section{Discussion}

The effects of the independent variables were generally small. The study results entailing age are consistent with the findings reported in the literature. Whereas personality traits change importantly in adolescence (Kawamoto \& Endo, 2015), they do not between 30 and 39 years of age (Kawamoto, 2016), at least in Japan. But systematic variation is observed over larger portions of the life-span in various countries (Edmonds, Goldberg, Hampson, \& Barckley, 2013; Milojev \& Sibley, 2014; Walton et al., 2013). Similar is the case of personality differences between the genders. Goodwin and Gotlib (2004) and Chapman, Duberstein, Sörensen, and Lyness (2007) in the United States; Weisberg, DeYoung, and Hirsh (2011) in Canada; León et al. (2017) in Peru; and Costa, Terracciano, and McCrae (2001) and Schmitt, Realo, Voracek, and Allik (2008) cross-culturally have reported greater Neuroticism, Volatility, and/or Withdrawal among females than males.

In the context of the significant differences in several of the 10 aspects of the Big Five observed along age and between genders in Table 1, the results regarding time in the public sector speak of important similarities between employees with large, some, or no experience with the public sector regarding nine of the 10 aspects. The low reliabilities of Industriousness and Orderliness do not appear to explain their lack of relationships with experience in the public sector; highly reliable aspects such as Volatility and Politeness also failed to correlate with it. The exception was Openness. Females exhibited greater scores on this variable, employees with experience in the public sector presented higher scores than personnel with experience only in the private sector, and the difference between sectors was especially pronounced among males.

No obvious interpretation of these results is available. The concept of person-organization fit suggests that people attracted to the public sector, especially men, are more likely to see beauty in things that others might not notice, frequently daydream, appreciate art, and need a creative outlet (De Young, 2014). However, theoretically, it is equally likely that years in the public sector cause frustration in the achievement of task goals and enhance these dispositions as escape routes. The nature of the sample grants greater credibility to the former interpretation. The sample was strongly biased toward the private sector. Even the participants who reported having one or more years working in the public sector had, on average, more years in the private sector. The emergence of differences in personality that are attributable to a very limited number of years in the public sector suggests that the employees arrived in the public sector already with greater Openness. This interpretation is consistent with the absence of a significant interaction of age with time in the public sector. Working in the public sector appears to grant lower social status than working in the private sector in Peru; perhaps an open mind is needed to transcend this perception, at least in the population targeted in this study. The significant interactive effects of gender and time in the public sector on Openness could be reflecting a greater Openness needed by men to enter an institution of lower social status. However, only longitudinal research will be able to produce evidence relevant to the direction of causality.

The self-selection of cases severely limits the external validity of the findings. The study was limited to persons who were attending executive extension courses at the leading university in the field of business management in Peru. It is unlikely that these persons are representative of the general population of Peruvian employees; they are probably more representative of skilled professionals and middlemanagement echelons who wish to advance their careers. Moreover, León et al. (2017) contributed the following observation: "the fact that the Big Five failed to materialize in the exploratory factor analysis could be explained by a response set of the participants. Experienced and competitive professionals may tend to supply answers contaminated by social desirability" (p. 126). 
Whether the findings are replicable in other countries or cultures is another question that the research leaves unanswered. But, for clarifying these types of issues are the replication studies. The present study just opened a line of research.

\section{References}

Chapman, B. P., Duberstein, P. R., Sörensen, S., \& Lyness, J. M. (2007). Gender differences in five factor model personality traits in an elderly cohort: Extension of robust and surprising findings to an older generation. Personality and Individual Differences, 43, 1594-1603. doi: 10.1016/j.paid.2007.04.028

Cooper, C. A., Knotts, H. G., McCord, D. M., \& Johnson, A, (2013). Taking personality seriously: the five-factor model and public management. The American Review of Public Administration, 43, 397. doi: 10.1177/0275074 012446509

Costa Jr., P. T., Terracciano, A., \& McCrae, R. R. (2001). Gender differences in personality traits across cultures: Robust and surprising findings. Journal of Personality and Social Psychology, 81, 322-331. doi: 10.1037//00223514.81.2.322

DeYoung, C. G. (2014). Openness/Intellect: A dimension of personality reflecting cognitive exploration. In M. L. Cooper and R. J. Larsen (Eds.), APA handbook of personality and social psychology: Personality processes and individual differences (Vol 4, pp. 369399). Washington, DC: American Psychological Association. doi: 10.1037/14343-017

DeYoung, C. G., Quilty, L. C., \& Peterson, J. B. (2007). Between facets and domains: 10 aspects of the Big Five. Journal of Personality and Social Psychology, 93, 880-896. doi:10.1037/0022-3514.93. 5.880

DeYoung, C. G., Quilty, L. C., Peterson, J. B., \& Gray, J. R. (2014). Openness to experience, intellect, and cognitive ability. Journal of Personality Assessment, 96, 46-52. doi: 10.1080/00223891.2013.806327

DeYoung, C. G., Weisberg, I. J., Quilty, L. C., \& Peterson, J. B. (2013). Unifying the aspects of the Big Five, the interpersonal circumplex, and trait affiliation. Journal of Personality, 81, 465-475. doi: 10.1111/jopy.12020
Edmonds, G. W., Goldberg, L. R., Hampson, S. E., \& Barckley, M. (2013). Personality stability from childhood to midlife: Relating teachers' assessments in elementary school to observer- and self-ratings 40 years later. Journal of Research in Personality, 47, 505-513. doi: 10.1016/ j.jrp.2013.05.003

Erdogan, B., \& Bauer, T. N. (2005). Enhancing career benefits of employee proactive personality: The role of fit with jobs and organizations. Personnel Psychology, 58, 859.981. doi: 10.1111/j.1744-6570.2005.00772.x

Flynn, N. (1993). Public sector management. $2^{\text {nd }}$ ed. Hemel Hemstead: Harvester Wheatsheaf.

Goodwin, R. D., \& Gotlib, I. H. (2004). Gender differences in depression: The role of personality factors. Psychiatry Research, 126, 135-142. doi: 10.1016/ j.psychres.2003.12.024

Hartnell, C. A., Ou, A. Y., \& Kinicki, A. (2011). Organizational culture and organizational effectiveness: A meta-analytic investigation of the Competing Values Framework's theoretical suppositions. Journal of Applied Psychology, 96, 677-694. doi: 10.1037/a0021987

Hirsh, J. B., DeYoung, C. G., Xu, X., \& Peterson, J. B. (2010). Compassionate liberals and polite conservatives: Associations of agreeableness with political ideology and moral values. Personality and Social Psychology Bulletin, 36, 655-664. doi: 10.1177/0146167210366854

Kaufman, S. B., Quilty, L. C., Grazioplene, R. G., Hirsh, J. B., Gray, J. R., Peterson, J. B., \& DeYoung, C. G. (2015). Openness to experience and intellect differentially predict creative achievements in the arts and sciences. Journal of Personality, 82, 248-258. doi: 10.1111/ jopy.12156

Kawamoto, T. (2016). Cross-sectional age differences in the HEXACO personality: Results from a Japanese sample. Journal of Research in Personality, 62, 1-5. doi: 10.1016/j.jrp.2016.03.001

Kawamoto, T., \& Endo, T. (2015). Personality change in adolescence: Results from a Japanese sample. Journal of Research in Personality, 57, 32-42. doi: 10.1016j. jrp.2015.03.002

Kristof, A. L. (1996). Person-organization fit: An integrative review of its conceptualizations, measurement, and implications. Personnel Psychology, 49, 1-49. doi: 10.11 11/j.1744-6570.1996.tb01790.x 
León, F. R., Morales, O., Vértiz, H., \& Burga-León, A. (2017). Universality of gender differences in 10 aspects of personality: A study of younger and older adult Peruvians. Personality and Individual Differences, 112, 124-127.

Lyons, H. Z., Brenner, B. R., \& Fassinger, R. E. (2005). A multicultural test of the theory of work adjustment: Investigating the role of heterosexism and fit perceptions in the job satisfaction of lesbian, gay, and bisexual employees. Journal of Counseling Psychology, 52, 537548. doi: 10.1037/0022-0167.52.4.537

Lyons, H. Z., \& O’Brien, K. M. (2006). The role of personenvironment fit in the job satisfaction and tenure intentions of African American employees. Journal of Counseling Psychology, 53, 387-396. doi: 10.1037/00220167.53.4.387

Milojev, P., \& Sibley, C. G. (2014). The stability of adult personality varies across age: Evidence from a two-year longitudinal sample of adult New Zealanders. Journal of Research in Personality, 51, 29-37. doi: 10.1016/ j.jrp.2014.04.005

Raman, P., Sambasivan, M., \& Kumar, N. (2016). Counterproductive work behavior among frontline government employees: Role of personality, emotional intelligence, affectivity, emotional labor, and emotional exhaustion. Journal of Work and Organizational Behavior, 32, 25-37. doi: 10.1016/j.rpto.2015.11.002

Roberts, B. W., \& Robins, R. W. (2004). Personenvironment fit and its implications for personality development: A longitudinal study. Journal of Personality, 72, 89-110. doi: 10.1111/j.00223506.2004.00257.x

Rustichini, A., DeYoung, C. G., Anderson, J., \& Burks, S. V. (2012). Toward the integration of personality theory and decision theory in the explanation of economic and health behavior. IZA Discussion Paper No. 6750. Bonn:
Institute for the Study of Labor. doi: 10.1016/j.soce c.2016.04.019

Saks, A. M., \& Ashforth, B. E. (1997). A longitudinal investigation of the relationships between job information sources, applicant perceptions of fit, and work outcomes. Personnel Psychology, 50, 395-426. doi: 10.1111/j.1744-6570.1997.tb00913.x

Schmitt, D. P., Realo, A., Voracek, M., \& Allik, J. (2008). Why can't a man be more like a woman? Sex differences in Big Five personality traits across 55 cultures. Journal of Personality and Social Psychology, 94, 168-182. doi: 10.1037/a0014651

Sekiguchi, T. (2004). Towards a dynamic perspective of person-environment fit. Osaka Keidai Ronshu, 55, 177-199.

Van der Haydn, B. I. J. M. (2006). Age differences in career activities among higher-level employees in The Netherlands: A comparison between profit-sector and non-profit sector staff. International Journal of Training and Development, 10, 98-120. doi: 10.1111/ j.1468-2419.2006.00247.x

Walton, K. E., Huyen, B. T. T., Thorpe, K., Doherty, E. R., Juarez, B., D’Accordo, C., \& Reina, M. T. (2013). Crosssectional personality differences from age 16-90 in a Vietnamese sample. Journal of Research in Personality, 47, 36-40. doi: 10.1016/j.jrp.2012.10.011

Weisberg, Y. J., DeYoung, C. G., \& Hirsh, J. B. (2011). Gender differences in personality across the ten aspects of the Big Five. Frontiers in Psychology, 2, 178. doi: 10.3389/fpsyg.2011.00178

Zaidi, N. R., Wajid, R. A., Zaidi, F. B., Zaidi, G. B., \& Zaidi, M. T. (2013). The big five personality traits and their relationships with work engagement among public sector university teachers of Lahore. African Journal of Business Management, 7, 1344-1353.

\section{Federico R. León}

MA Detroit, PhD Maryland, Postdoc Toronto. From 1964 to 2010, his interests evolved from clinical to organizational and then to health psychology. Presently, he conducts research on individual differences and psychological effects of geography. He works for Vicerrectorado de Investigación and teaches at the Graduate School of Universidad San Ignacio de Loyola.

* federicorleone@gmail.com. 